\title{
Letting Nebuchadnezzar Speak: The Purpose of the First-Person Narrative in Daniel 4
}

\author{
WENDY L. WIDDER (UNIVERSITY OF THE FREE STATE)
}

\begin{abstract}
This article proposes that the use offirst-person narration in the unusual literary structure of Dan 4 creates the most meaningful message for the diaspora audience of the book because of who Nebuchadnezzar was and when the events were purported to occur. It discusses the larger literary context of the chapter and its narrative structure, analyses the text and identifies important elements highlighted by the use of different narrative voices, and considers how the structure shapes the message of the chapter. Nebuchadnezzar was the king who defeated Israel's God (Dan 1:1-2) and changed life forever for God's people, yet at the peak of Nebuchadnezzar's power, that same God humbled him such that he came to acknowledge the superior sovereignty of Israel's God. By framing the account of this transformation as a proclamation in Nebuchadnezzar's own words to the entire world, the author of Daniel vindicates the God of Israel before the whole world and transforms the king who embodied opposition to God into the paradigm of what a gentile king ought to be.
\end{abstract}

KEYWORDS: narrative, narrative voices, first-person, Daniel, Nebuchadnezzar

\section{A INTRODUCTION}

Nebuchadnezzar is the most colourful character in the book of Daniel, dominating the landscape of its first four chapters. The Babylonian king makes his final appearance as an active character in chapter 4, when he is troubled by a dream about a great tree cut down to the ground by divine order. ${ }^{1}$ When

* Submitted 25/02/2019, reviewed 10/04/2019, accepted 04/05/2019. Wendy L. Widder, "Letting Nebuchadnezzar Speak: The Purpose of the First-Person Narrative in Daniel 4," Old Testament Essays 32 no. 1 (2019): 197-214. DOI: https://doi.org/ 10.17159/23123621/2019/v32n1a11.

1 The MT and English translations have different versifications for this account. The MT's account begins with Nebuchadnezzar's statement that he was contented and prospering when he had the troubling tree dream (4:4 in English translations, 4:1 in the MT), while English translations begin the story with 3:31 of the MT, where the king announces his proclamation. Chapter divisions are usually credited to Archbishop Stephen Langton in the thirteenth century, and while most modern Christian translations have rejected Langton's chapter division here, printed editions of the MT retain it, perhaps because other Danielic narratives (e.g., Dan 2, 3, 6) conclude with similar praise of the God of Heaven. The larger issue of variation in textual witnesses 
Nebuchadnezzar's Babylonian experts prove inadequate to interpret the dream, Daniel interprets it and calls the king to repentance. Twelve months later, Nebuchadnezzar's boastful words trigger the fulfilment of the dream: he is driven from his throne to dwell with the beasts until he acknowledges the sovereignty of the Most High and is ultimately restored to greatness.

The account of Nebuchadnezzar's humbling is presented as a royal proclamation written in the first person and issued by the Babylonian king to all the inhabitants of his vast empire. Within this first-person narrative is a thirdperson section in the voice of an anonymous narrator. A long-standing question of scholarship is why this narrative account has two distinct voices woven together in this unusual way. 2 One response is that the alternation between firstand third-person narration is the result of the text's redactional history. $3 \mathrm{~A}$ second response is that genre was the primary motivation: since "the chapter's dominant formal features are those of a dream report ... and confessional praise," the use of first person was "natural," while the insertion of the third-person narrative was "dramatically appropriate." 4 A third response is that, while genre considerations and a complex compositional history may well have factored into the extant text of the MT, the alternation of first and third person is first and foremost a literary feature that serves the purposes of the story.5

Among those who assume intention (i.e., the second and third responses above), a common explanation for the use of the first person is that the royal letter from Nebuchadnezzar gives the account a special kind of authority, ${ }^{6}$ while

for the text of Dan 4 is beyond the scope of this article, but see further John J. Collins, Daniel, Hermeneia (Minneapolis: Fortress, 1993), 2-12, 216-21; James A. Montgomery, A Critical and Exegetical Commentary on the Book of Daniel, ICC (New York: Scribner's Sons, 1927), 223-24, 247-49. I will use the MT versification throughout with the English bracketed, but I will refer to the pericope as "chapter 4" or "Dan 4" for the sake of simplicity.

2 While the use of the first person is common in biblical poetry and prophetic literature, its use in biblical narrative is primarily limited to reported speech embedded in third-person narratives (e.g., Gen 3:2, 10, 12; Dan 1:10, 12-13). The exceptions include Nehemiah, written primarily in first person, and Ezra, where Ezra narrates chapters 8 and 9 in first person. The narrative chapters of Daniel (chs. 1-6), with the exception of Dan 4, are told in the voice of the anonymous narrator.

3 E.g., Collins, Daniel, 216. Given the differences between the OG and the MT, as well as the question of the relationship between Dan 4 and the Nabonidus accounts, it seems likely that a complex compositional and tradition history underlies the narrative structure of Dan 4. See further Ernest C. Lucas, Daniel, AOTC 20 (Downers Grove, IL: InterVarsity Press, 2002).

4 John E. Goldingay, Daniel, WBC 30 (Dallas: Word, 1989), 82.

5 E.g., Carol A. Newsom with Brennan W. Breed, Daniel, OTL (Louisville, KY: Westminster John Knox, 2014); Sharon Pace, Daniel, SHBC (Macon, GA: 2008).

$6 \quad$ E.g., Lucas, Daniel, 103. 
a common explanation for the insertion of the third-person section is that the king could hardly be expected to narrate his own insanity. ${ }^{7}$ These explanations have merit, but neither answers the more basic question of why the biblical narrator yielded the floor to Nebuchadnezzar at all, and why he did so without introducing the context or bringing the chapter to a conclusion. Nebuchadnezzar simply speaks, and the third-person insert is seamlessly integrated into the firstperson narration, such that the king's proclamation comprises the entire chapter.

In their commentaries, Sharon Pace and Carol Newsom show greater interest in this more basic question but reach opposite conclusions. Pace argues that the text is "purposely designed to showcase Nebuchadnezzar's pride, to underscore God's trustworthy revelation to the hero, and to emphasize God's sovereignty." 8 She posits that the author constructed two accounts of Nebuchadnezzar's dream - the first-person narration of the king's letter and the third-person section of the biblical narrator. These two accounts were combined "to construct two implied groups - the recipients of Nebuchadnezzar's letter alone and the readers of the entire account." 9 She contends that Nebuchadnezzar's account omits the interpretation and humbling because the author wanted to portray that although "Nebuchadnezzar ultimately recognizes God's power over earthly sovereigns... he remains blind to its implications," and ultimately, his character was unchanged. ${ }^{10}$ By contrast, Newsom argues that use of first person “takes the reader into Nebuchadnezzar's own mind and makes him the primary witness to the transformation in understanding that he has undergone."11 She contends that the third-person section tempers the portrayal of Nebuchadnezzar from chapters 2 and 3, allowing "critical aspects of the meaning of Nebuchadnezzar's experience to be framed" by the trustworthy voice of the biblical narrator (and Daniel). ${ }^{12}$ This switch between persons "well serves the narrative and thematic purposes" of the larger cycle of Nebuchadnezzar stories in the book of Daniel. ${ }^{13}$

My own view aligns more closely with Newsom's, and in what follows I will engage her commentary as appropriate. I am particularly interested in why the author used the first person at all, rather than simply reporting what happened, as he did in the earlier chapters. According to Newsom, the use of Nebuchadnezzar as the "primary witness" to his transformation makes the

7 See, e.g., Lucas, Daniel, 104; Montgomery, Daniel, 223. In this vein, Danna Nolan Fewell wonders if the king could be trusted to tell his own story ("A madman is prone to make an unreliable narrator," Circle of Sovereignty: Plotting Politics in the Book of Daniel [Nashville: Abingdon, 1991], 75).

8 Pace, Daniel, 118.

9 Pace, Daniel, 119.

10 Pace, Daniel, 117.

11 Newsom, Daniel, 133.

12 Newsom, Daniel, 133.

13 Newsom, Daniel, 133. 
Babylonian king "into a fully rounded character in a way that none of the [other chapters] do."14 I agree, but to what end? In this article I propose that the use of the first person in Dan 4 creates the most meaningful message for the diaspora audience of the book because of who Nebuchadnezzar is and when the events are purported to have happened. In support of this proposal, I will first discuss the larger literary context and the narrative structure of Dan 4. Then I will analyse the text and identify important elements highlighted by the use of different narrative voices. Finally, I will consider how this unique structure shapes the message of the chapter.

\section{B CONTEXT AND STRUCTURE}

\section{Literary Context}

The book of Daniel comprises two primary genres: narrative stories in chapters 1-6 and apocalyptic visions received and reported by Daniel in chapters 7-12. Daniel 4, like its surrounding narratives, is usually considered a court narrative, a type of ancient Near Eastern story that recounts the intrigues and adventures of royal courtiers. Within this corpus are tales of foreign courtiers who outshine the regular royal staff and receive great rewards for their efforts. ${ }^{15}$ Niditch and Doron detail four "major plot events" of a court story: "(1) A person of lower status...is called before a person of higher status...to answer difficult questions or to solve a problem requiring special insight.... (2) The person of high status poses the problem which no one seems capable of solving. (3) The person of lower status...does solve the problem. (4) The person of lower status is rewarded."16 Given these "major plot events," Dan 4 falls short of a typical court story. Its focus is not on the success of Daniel, the courtier. Rather, its focus is on the fulfilment and significance of Nebuchadnezzar's dream. While it may have its roots in a court story, Dan 4 is much adapted from typical court stories to suit the purposes of the author. ${ }^{17}$

More important than any affinities Dan 4 may have with the court story genre is its place in the broader literary context of Daniel's narratives. Daniel 4

14 Newsom, Daniel, 133. She also considers one outcome of the chapter to be that Nebuchadnezzar serves "as a symbol for all Gentile rulers" (Daniel, 130). Again, I agree, but surely the author could have accomplished this portrayal without the voice of Nebuchadnezzar.

15 See further Collins, Daniel, 39; Lawrence M. Wills, The Jew in the Court of a Foreign King: Ancient Jewish Court Legends, HDR 26 (Minneapolis: Fortress, 1990), 1-31; Goldingay, Daniel, 36-37.

16 Susan Niditch and Robert Doran, "The Success Story of the Wise Courtier: A Formal Approach,” JBL 96 (1977): 180.

17 Newsom notes, "The MT lightly shapes the narrative as a court contest by having the king summon the sages of Babylon....That this is not the primary genre of the story is evident from the fact that Daniel vanishes from the story after giving his interpretation" (Daniel, 133). 
is the third and final story in which gentile king Nebuchadnezzar encounters the God of Israel through his interactions with the Judean exiles. ${ }^{18}$ As such, the chapter offers the book's final look at Nebuchadnezzar and invites consideration of the Babylonian king's development as a character, as well as his role in the book as a whole. Newsom says "Daniel 4 plays a climactic role in the sequence of stories in Dan 1-6," since-whatever their compositional and tradition history - the first four chapters "have been carefully edited together to provide an extended account of the gradual transformation of Nebuchadnezzar's consciousness from a king who considers himself to be the most powerful figure in his kingdom to one who recognizes that his extraordinary greatness is but a gift from the Most High God." 19 Why the author of Daniel is concerned to portray this transformation is what I am considering in this article.

\section{Narrative Structure}

The narrative structure of Dan 4 begins and ends with sections written in the first person and purported to be the words of King Nebuchadnezzar as he reflects on the events surrounding a troubling dream about a magnificent tree (3:31$4: 15[4: 1-18]$ and 4:31-34[34-37]). Between these first-person accounts is a third-person section (4:16-30[19-33]). This section is in the biblical narrator's voice and includes a description of Daniel's response to the king's dream report (4:16[19]), his repetition and interpretation of the dream (4:16-23[19-26]), and the biblical narrator's account of the dream's fulfilment (4:25-30[28-33]). Within this structure is extensive repetition, as three different voices in the narrative recount elements of the dream, its interpretation, and fulfilment: the king's voice (4:7-14[10-17]), Daniel's (4:16-24[19-27]), and the biblical

18 Daniel 1 falls roughly in this group of stories, but Nebuchadnezzar is less a character than a prop in the events there.

19 Newsom, Daniel, 127. She also discusses the link between Dan 4 and Dan 5, the story of Belshazzar, calling "the redeemed Nebuchadnezzar...a foil over against his weak and arrogant son, Belshazzar" (Daniel, 127). I don't disagree, but that discussion takes us into the larger issue of the Aramaic chiastic structure of chs. 2-7 and its significance in the book - an article in itself. At the very least, the accounts of Nebuchadnezzar's humbling and Belshazzar's pride together form the heart of the chiastic structure, conveying what may well be the primary theme of the structure (and even the book). In both chapters, proud human kings encounter the God who granted them power, and each king responds differently to the reckoning. In Dan 4, Nebuchadnezzar acknowledges the supreme authority of the Most High, while in Dan 5, Belshazzar is unfazed by God's claim to authority (see 5:22-23). Each story also recounts God's response to each king, restoring Nebuchadnezzar to power and irrevocably removing Belshazzar's power. A driving theme of the book of Daniel is the relationship between human kings and the divine king, human authority and divine authority. Nowhere in the book is this theme more clearly on display than in the accounts of Dan 4 and 5, where two gentile kings overreach their God-ordained authority and faced God's judgment. 
narrator's (4:25-30[28-33]). This repetition invites comparison and contrast of the various accounts, which in turn reveals elements of importance to the respective voices.

1. First Person: Nebuchadnezzar's Reflection (3:31-4:15[4:1-18])

a. The Context $(3: 31-33[4: 1-3])$

b. The Content (4:1-15[4-18])

2. Third Person: Nebuchadnezzar's Humbling (4:16-30[19-33])

a. The Humbling Predicted (4:16-24[19-27])

b. The Humbling Fulfilled (4:25-30[28-33])

3. First Person: Nebuchadnezzar's Restoration (4:31-34[34-37])

a. Acknowledgment and Restoration (4:31-33[34-36])

b. A Final Word (4:34[37])

That much of this account is crafted as reported speech of Nebuchadnezzar is important to its meaning. Reported speech in the biblical text is not a transcription of what anyone really said; rather, like everything else in biblical narrative, it represents the biblical narrator's interpretation of what was said. ${ }^{20}$ Biblical narrators shape the speech of characters to emphasize particular things and, more importantly, to influence the reader's perception of the one speaking and of the events. Of reported speech in the Bible, Bar-Efrat says:

Conversations in biblical narrative are never precise and naturalistic imitations of real-life conversations. They are highly concentrated and stylized, are devoid of idle chatter, and all the details they contain are carefully calculated to fulfil a clear function. Moreover, the conversations are sometimes so compressed that the details we want or expect to find in them are missing. ${ }^{21}$

20 In Chatman's words, everything is "mediated" by the author (Seymour Chatman, Story and Discourse: Narrative Structure in Fiction and Film [Ithaca, NY: Cornell University Press, 1978], 33). This is especially important to remember in a text like Dan 4, which purports to be a letter composed by Nebuchadnezzar-and thus has the appearance of "an unmediated narrative text" (171); regardless of one's view of the historicity of the letter or the events it describes, the letter has still been "mediated" by the author of Daniel to fit his purposes. See note 25.

21 Shimon Bar-Efrat, Narrative Art in the Bible (New York: T\&T Clark, 2004), 6465 . 
Furthermore, while reported speech develops the plot of biblical stories, it also provide windows into the thoughts, interests, and motivations of their speakers. Says Bar-Efrat,

All speech reflects and exposes the speaker, while it sometimes also brings to light qualities of the person being addressed (or reveals the speaker's opinion of that person). What people say witnesses not only to their thoughts, feelings, etc., but is often slanted to accord with the character, mood, interests and status of their interlocutor. ${ }^{22}$

Given this, the use of first person for much of Dan 4 is particularly noteworthy. Nebuchadnezzar has been a main character for two chapters (chs. 2-3), as well as being important to the events of chapter 1. Chapters 2 and 3 are third-person accounts, which means our view of the Babylonian king has come through the voice of the biblical narrator. ${ }^{23}$ What would be the purpose of switching to the first person in Dan 4? Additionally, why did the biblical narrator place the king's words in the form of an open letter to the empire and then let that letter stand without a third-person narrative framework to provide context. ${ }^{24}$ The chapter begins and ends in the voice of Nebuchadnezzar.

Nebuchadnezzar's story is set as reported speech from the king himself because the reader is supposed to learn about him from what he says. If the point of the narrative was simply to communicate that the proud Nebuchadnezzar was humbled until he acknowledged the superiority of the Most High God, the biblical narrator could have narrated the events. Instead, he crafted the account of Nebuchadnezzar's humbling as a first-person account by the king himself, and by doing so invites the reader to consider what the king's words tell us about him. In Dan 2 and 3, the biblical narrator told tales about Nebuchadnezzar's encounters with Israel's God, and now the reader finally hears from the king in his own words. This chapter is Nebuchadnezzar's day in court. The king speaks, and the reader is invited to weigh his words, render a verdict on their validity, and reflect on the character of the person behind them.

However, weighing the king's words requires a reliable standard. Herein lies the reason for the alternation between first and third person in Dan 4: the

22 Bar-Efrat, Narrative Art in the Bible, 148.

23 Nebuchadnezzar does have reported speech in both Dan 2 and 3, and these speeches do reveal his character and motivation. The chapters themselves, however, are thirdperson stories with his reported speech embedded.

24 Questions of historicity (whether with respect to the empire-wide proclamation or the events themselves) are not at issue here. Regardless of whatever history it may or may not record, this narrative was composed by the biblical authors in language that would make the relevant theological points and resonate with the Jewish audience of the book. See further V. Philips Long, The Art of Biblical History (Grand Rapids: Zondervan, 1994), for the character of biblical historical narrative in terms of "pictures" versus "portraits" or representations of the events. 
reader needs a benchmark for assessing the validity of Nebuchadnezzar's claims. In chapters 2 and 3, Nebuchadnezzar showed himself to be unreasonable and even irrational (see Dan 2:5-6, 8-9, 12; Dan 3:13-15, 19-22, 29). How should we understand him in Dan 4 ? The presence of the third-person biblical narrator in Dan 4:16-30[19-33] brings the omniscient and reliable narrator's voice into this story and into the group of Nebuchadnezzar stories at a critical place. Newsom elaborates:

The narratives have traced Nebuchadnezzar's gradual and erratic awareness of the nature and power of the God of Daniel, as the king moves from ignorance (1:17-20) to cognizance of this deity's ability to reveal mysteries $(2: 47)$, then to a recognition of his power to thwart the king's decree and save his devotees (3:28-29). Yet it has not been clear that Nebuchadnezzar has actually grasped the full implications of his own statement that this deity must therefore be the 'Lord of kings' $(2: 47)$... Since Nebuchadnezzar's understanding in chapters 2 and 3 was demonstrably flawed, a wholly first-person narration in chapter 4 might leave the reader uncertain as to whether Nebuchadnezzar's account could be fully trusted. The third-person sections allow critical aspects of the meaning of Nebuchadnezzar's experience to be framed by...the anonymous narrator. ${ }^{25}$

The biblical narrator reports the meaning, significance, and fulfilment of Nebuchadnezzar's tree dream, using his own words and the reported speech of Daniel (4:16-30[19-33]). ${ }^{26}$ It is this third-person section that allows the reader to assess the validity of the king's words. ${ }^{27}$

In what follows, I consider each of the three major sections in the narrative, highlighting areas of the king's speech that particularly reflect his thoughts and assessing the validity of his words by means of the third-person narrative.

\section{ANALYSIS OF THE TEXT}

\section{First Person: Nebuchadnezzar's Reflection (3:31-4:15[4:1-18])}

The account begins abruptly in the king's voice without a third-person biblical narrator to frame the account that follows. The author uses Nebuchadnezzar's

\footnotetext{
25 Newsom, Daniel, 133.

26 One could arguably dispute the trustworthiness of Daniel's reported speech, but the omniscient narrator has presented him throughout the book as God's faithful and trustworthy servant.

27 The first-person accounts are thus "unreliable narration" and "at odds with the implied reader's surmises about the story's real intentions" (Chatman, Story and Discourse, 233) - that is, readers of the book of Daniel (not the world-wide audience of the chapter's letter) are still uncertain whether Nebuchadnezzar can be trusted. The voice of the trusted narrator is required to confirm Nebuchadnezzar's words.
} 
voice to provide the context $(3: 31-33[4: 1-3])$, which is set in the traditional framework of Aramaic letters. The declaration begins by identifying Nebuchadnezzar the king as the speaker and his audience as "all peoples, nations, and languages which live in all the earth" (v. 31[4:1]). Lucas comments that the words Nebuchadnezzar uses to describe the addressees of his letter "make him an epitome of human kingship in their claim to universal rule." ${ }^{28}$ What the greatest king of the day has to say is of universal significance: everyone everywhere should take note. ${ }^{29}$

The king then summarizes the significance of the reflection to follownamely, he is recounting the "signs and wonders" the Most High God had performed for him in demonstration of the superiority of his kingdom. This statement has at least two points of relevance. The first is the use of "signs and wonders," an expression used throughout the Hebrew Bible to refer to miraculous acts of God-and most frequently those associated with the exodus (e.g., Exod 7:3; Deut 6:22; 7:19; 26:8; 34:11; Jer 32:20-21; Ps 135:9; Neh 9:10), which God performed so that pharaoh, the Egyptians, and God's own people would acknowledge YHWH's superior power over pharaoh and the Egyptian gods (Exod 6:7; 7:5, 17; 8:18; 14:4, 18). ${ }^{30}$ The expression here in Dan 4 likely a signal to knowledgeable readers that Israel's God was about to demonstrate his superior power again. The repeated purpose of what befalls Nebuchadnezzar is "that the living may know that the Most High is ruler over the kingdom of mankind, and to whomever he wishes, he gives it, and the lowliest of men he sets over it" (v. 14[17]; cf. vv. 22[25], 29[32]). In showcasing his superior power, the Most High God brought Nebuchadnezzar to a place of acknowledging his supremacy over all kingdoms and kings. Nebuchadnezzar is making a universal statement to a universal audience.

The second relevant element in Nebuchadnezzar's opening words is his reference to "the Most High God" (v. 32[4:2]), a title he uses throughout his account (vv. 32[4:2], 14[17], 21[24], 22[25], 29[32], 31[34]). Elsewhere in Daniel this title occurs only in 3:26, when Nebuchadnezzar ordered Shadrach, Meshach, and Abednego out of the fiery furnace, recognizing their god/God as the one with unrivalled power to deliver $(3: 29$; cf. $3: 15)$; in $7: 25$, where the holy ones of the Most High God are promised the kingdom; and in Dan 5's summary

28 Lucas, Daniel, 108.

29 At this point in the narrative, Chatman's "parties to the narrative transaction" are clearly identifiable: the implied author is the author of Daniel; the (explicit) narrator of this account is Nebuchadnezzar; the narratees are "all peoples, nations, and languages which live in all the earth" (Dan 3:31[4:1]); and the implied readers are diaspora Jews (Story and Discourse, 233).

30 Of this connection to the exodus, Newsom notes, "Thus the Egyptian Pharaoh and the Babylonian Nebuchadnezzar are paralleled as monarchs who experience the power of the Israelite God" (Daniel, 134). 
of Dan 4's events $(5: 18,21) .{ }^{31}$ Its pervasive use in Dan 4 makes it thematically significant, and Newsom notes that the doxology of v. 33[4:3] makes this significance explicit: "What distinctively characterizes the Most High's sovereignty is its duration." 32

The first-person section then moves to Nebuchadnezzar's report of his terrifying dream, in which he provides the initial account of the dreaminformation that will be repeated with variation multiple times in the chapter (4:1-15[4-18]). This initial telling sets up the comparison and contrast with subsequent accounts in the chapter.

The background of the king's dream was a time that he was "at ease ... and flourishing" in his palace (4:1[4]). Nebuchadnezzar was at the peak of his reign. When the troubling dream disturbed him, his experts were unable to help until finally Daniel came. Nebuchadnezzar describes Daniel by name ("Belteshazzar, after the name of my god"33) and by what the king considered his unique qualification to interpret the dream ("the spirit of the holy gods is in him," v. 5[8]; cf. v. 6[9]).

The king then recounts his dream in two distinct sections. In the first he describes the great tree (vv. 7-9[10-12]), and in the second he recounts the watcher's command to destroy the tree (vv. 10-14[13-17]). Nebuchadnezzar's description of the magnificent tree has three elements that are not part of Daniel's near verbatim retelling of the dream: (1) the tree was in the middle of the earth (v. 7[10]); (2) the height of the tree was great (v. 7[10]); and from the tree "all flesh was being sustained" (v. 9[12]). These additional descriptions may hint at the king's perception of what is important: the tree's magnitude and beneficence, imagery that clearly indicates his greatness.

In the second section of the dream report, Nebuchadnezzar recounts the watcher's command to destroy the tree. He introduces the command with a redundant and descriptive speech frame, "he was calling out loudly and thus he was saying" (v. 11[14]), a lengthy introduction that probably indicates the shocking nature of the speech that follows. ${ }^{34} \mathrm{He}$ then reports in a series of

31 The shorter title "Most High" is used in 7:18, 22, 27.

32 Newsom, Daniel, 135.

33 Although the etymology is false, it "plays a thematic role in the story... since what Nebuchadnezzar will learn is that his kingship comes not from [his god] but from 'the Most High,' that is, the God of Israel" (Newsom, Daniel, 136).

34 See 4:20[23], where Daniel's retelling sets up this reported speech with saying." See Steven E. Runge and Joshua R. Westbury, Lexham Discourse Hebrew Bible: Introduction (Bellingham, WA: Lexham, 2012), 1.5 (Redundant Quotative Frames). See also Steven E. Runge, Discourse Grammar of the Greek New Testament: A Practical Introduction for Teaching and Exegesis (Peabody, MA: Hendrickson), 145-52; and see Josh Westbury, "Quotative Frames and the Power of Redundancy" 
staccato imperative, jussive, and verbless clauses the watcher's orders to destroy the tree, scatter its inhabitants, and preserve the stump (vv. 11-13[14-16]). The imagery of the watcher's pronouncement shifts from trees to beasts and humans: the stump is to eat plants with the beasts while its human mind became the mind of a beast. The relative clarity of the watcher's command with respect to this cosmic tree - a widespread motif in the ancient Near East - makes it difficult to believe that Nebuchadnezzar did not have a general understanding of what his dream meant. ${ }^{35}$ His lengthy reporting of the watcher's command (cf. Daniel's brief retelling in v. 20[23]) probably reflects this. Since the watcher's words most directly affected him, he had good reason to recall every vivid detail.

The initial first-person narrative of the king comes to a close with Nebuchadnezzar's request that Belteshazzar/Daniel interpret the dream ( $\mathrm{v}$. 15[18]; cf. v. 6[9]).

\section{Third Person: Nebuchadnezzar's Humbling (4:16-30[19-33])}

The second major section of the chapter shifts to the third person, where the voice of the biblical narrator recounts Daniel's reaction to the king's dream before presenting Daniel's interpretation of the dream (4:16-24[19-27]) and its fulfilment (4:25-30[28-33]). ${ }^{36}$ In the literary structure of the chapter, this section functions in at least two ways relevant to the discussion here. First, by providing a second account of the king's dream, it invites comparison and contrast with the king's account in the first section (4:6-15[9-18]). Second, it brings the voice of the omniscient and reliable biblical narrator into this story and offers the standard against which the king's earlier words can be weighed.

The biblical narrator reports that Daniel was appalled by the king's dream, but at the king's encouragement, he interpreted it. Newsom notes that both Daniel's reaction and the exchange between Nebuchadnezzar and Daniel in v. 16[19] "suggest a degree of genuine affection between them," and the purpose

(https://academic.logos.com/quotative-frames-and-the-power-of-redundancy/) for numerous Old Testament examples of the effect of redundancy on discourse.

35 One also wonders whether the king's wise men knew what the dream meant but did not want to say. Since everything thus far has been relayed from Nebuchadnezzar's point of view, all we know is that his men did not interpret it (v. 4[7]) because the king said they could not (v. 15[18]). If they understood the dream, they may have needed another source of divination to confirm its meaning of the dream (see A. Leo Oppenheimer, "The Interpretation of Dreams in the Ancient Near East," TAPA 46, n.s. [Philadelphia: The American Philosophical Society, 1956] and Jean Bottéro, Religion in Ancient Mesopotamia [trans. Teresa Lavender Fagan; Chicago: University of Chicago Press, 2001], 176-86). Since the dream was not from one of their gods, they would have had no access to another means of divination for confirmation. Daniel, however, knew the message was from his God and did not need to confirm its meaning. 36 Daniel's interpretation is set as his reported speech, embedded in the biblical narrator's account. 
of including these details in the third-person narrative "appears to be to orient the reader's attitude toward the king," who has been "ambivalently portrayed" up to this point in the cycle of Nebuchadnezzar stories. While the judgment of chapter 4 "implies divine displeasure ... the purpose of the narrative is to depict the redemption of the king," and Daniel's reaction to the dream encourages the reader to be sympathetically inclined toward the king. ${ }^{37}$

Daniel's interpretation alternates between his description of the dream itself and then the interpretation of various elements. He begins with a description and interpretation of the tree (4:17-18[20-21]; 4:19[22]), echoing much of what Nebuchadnezzar himself had said. However, as noted above, Daniel's description does not include three elements that the king had included: (1) the tree's central position in the earth; (2) the tree's great height (v. 7[10]); (3) that all flesh was sustained by the tree, saying instead that "food for all" was on it (v. 18[21]; cf. v. 9[12]). His omission of the first two elements may indicate that the great king's self-perception was overblown, while his adaptation of the third implies that the king had the resources to care for all the inhabitants of his kingdom but had not done so.

The second part of Daniel's description and interpretation is in 4:2123[24-26], where he recounts the command of the watcher. As noted above, this portion of Daniel's retelling is markedly shorter than the king's version, probably due to the fact that the details were particularly vivid to the king, the one most affected by the events portrayed. ${ }^{38}$

Daniel concludes his response to Nebuchadnezzar with a word of unsolicited counsel to repent and reform (4:24[27]). His call to do righteousness and mercy with respect to the poor $(\mathrm{v} .24 \mathrm{~b}-\mathrm{c}[27 \mathrm{~b}-\mathrm{c}])$ is further indication that the king had not fulfilled his responsibility to care for all the inhabitants of his kingdom.

The third-person portion of the narrative then moves to the voice of the biblical narrator, recounting the events behind the fulfilment of the dream (4:2530 [28-33]). The narrator first reports Nebuchadnezzar's act of hubris that set the decree of the Most High in motion (4:26-27[29-30]), and then he details the fulfilment of the dream (4:28-30[31-33]). From atop his palace, Nebuchadnezzar surveyed the great city beneath him and boasted of his part in its greatness, his words recalling Daniel's interpretation of his first dream, where Daniel told him that God had given him the kingdom, the power, the strength, and the honour (Dan 2:37; cf. 4:27[30]). At this flourishing peak of his career in

\footnotetext{
37 Newsom, Daniel, 143.

38 Daniel's omissions may also reveal a lot about Daniel, who the reader knows to be troubled by what would befall the king. See further Wendy L. Widder, Daniel, SGBC (Grand Rapids: Zondervan, 2016), 94-96.
} 
Dan 4, Nebuchadnezzar laid claim to all that God had given him, demonstrating his failure to learn the lesson deduced from his earlier dream.

Instantly Nebuchadnezzar's judgment was enacted. The narrator reports a voice descending from heaven and decreeing the king's demise. Then he details the fulfilment in which the greatest king of the day became beast-like. ${ }^{39}$

\section{First Person: Nebuchadnezzar's Restoration (4:31-34[34-37])}

The narrative then shifts back to the first-person voice of Nebuchadnezzar, as the king concludes his reflection. He first details the outcome and effect of his encounter with the Most High and then reiterates his praise of the Most High God in words that echo his opening words of praise, forming an inclusio that highlights the chapter's theme of God's superior kingdom (cf. 3:31-33[4:1-3]). In the closing words of the chapter, Nebuchadnezzar's final words in the book, the king describes his restoration and acknowledges the sovereignty of the "king of heaven," who does what is right and humbles those who walk in pride.

The king's words begin with a temporal clause that sets the context: "At the end of the days, I, Nebuchadnezzar, my eyes to the heavens lifted," a reference to the "seven times" decreed for the king's judgment (vv. 13[16], 20[23], 22[25], 29[32], 30[33]). That the king lifted his eyes to heaven suggests he was seeking God's help (Pss 25:15; 121:1-2; 123:1-2; 141:8), ${ }^{40}$ an action that appears to prompt the restoration of his reason. ${ }^{41}$ As his sanity was returning to him, ${ }^{42}$ Nebuchadnezzar praised the Most High for his sovereignty, fulfilling the stated purpose of his judgment (vv.14[17], 22[25], 29[32]). Since the judgment was to last "until you acknowledge that the Most High is ruler over the kingdom of mankind, and to whomever he wishes, he gives it." (vv. 14[17], 22[25], 29 [32]), the reader can assume that the restoration of the king indicates that Nebuchadnezzar does, in fact, acknowledge these things, as his words indicate he does.

It is interesting that, in a chapter full of repetition, Nebuchadnezzar does not echo the required acknowledgement as stated in vv. 14[17], 22[25], 29[32] and simply says, "I praised and honoured the Most High, who is ruler over the kingdom of mankind and gives it to whomever he wishes." Rather, he details two

39 Fewell notes the poetic justice: "A man who thinks he is like a god must become like a beast to learn that he is only a human being" (Circle of Sovereignty, 72).

40 Goldingay, Daniel, 90.

41 Newsom notes that this action is in line with Nebuchadnezzar's animalistic state: "He cannot speak, but he signals as an animal might, by directing his eyes to heaven. In response to this gesture of acknowledgement, his reason is restored" (Daniel, 148).

42 I read the imperfect verb ית: in 4:31b[34b] as circumstantial: "And as my reason to me was returning." See Tarsee Li's discussion on the prefix conjugation in Dan 4:3133[34-36] in The Verbal System of the Aramaic of Daniel: An Explanation in the Context of Grammaticalization, SAIS 8 (Leiden: Brill, 2009), 106-8. 
reasons for his praise and acknowledgment of God's sovereignty: (1) the everlasting nature of the Most High and his kingdom (v. 31[34]); (2) the power he demonstrates (v. 32[35]). The first of these reasons reiterates what he said in the opening verses of the chapter $(3: 33 \mathrm{c}-\mathrm{d}[4: 3 \mathrm{c}-\mathrm{d}])$, creating an inclusio that highlights the theme of God's enduring and thereby superior kingdom. In v. 32[35], Nebuchadnezzar explains the second of his reasons in language reminiscent of other Old Testament texts: "all the inhabitants of the earth are considered nothing" recalls Isa 40:17 ("All the nation are like nothing before him; they are regarded as worthless and less than nothing by him"); "according to his will, he does with the host of heaven and the inhabitants of the earth" recalls Ps 115:3 ("Our God is in heaven; whatever he pleases, he does") and Ps 135:6 ("Whatever pleases YHWH, he does, in the heavens and on the earth, in the seas and all the depths"); "There is no one who strikes his hand and says to him, 'What have you done?"' recalls Job 9:12 ("Who can say to [God], 'What are you doing?"') and Job 42:2 ("I know that you can do everything; no purpose of yours can be thwarted"). In shaping Nebuchadnezzar's words with this language, the author of Daniel makes them resonate with the book's audience to demonstrate the sincerity of the king's new understanding. ${ }^{43}$

Then the king resumes talking about his restoration. His mind was restored, as were his majesty and splendour. His officials sought him out again, and he was an even greater king than he had been before (v. 33[36]). While these closing words of the king may sound like the king had learned nothing from his humiliation, in the context of the chapter and the book, Nebuchadnezzar's words are appropriate. A focus of the book of Daniel is the relationship between human and divine kingship, and the book clearly casts Nebuchadnezzar's greatness as God's gift $(2: 37 ; 5: 18)$. Nebuchadnezzar's statement about his own greatness, glory, and majesty at the end of chapter 4 appears between two acknowledgments of God's greatness (vv. 31-32[34-35]; v. 34[37]). The reason for Nebuchadnezzar's judgment was not that he considered his kingdom great and glorious - it was great and glorious because God had made it so. The reason for Nebuchadnezzar's judgment was his failure to acknowledge the source of his greatness. He took credit for it rather than acknowledging that the Most High ruled over him and had given him dominion. The events of chapter 4 transformed the king's perspective on his place in the hierarchy of sovereignty.

In his final words of the book, Nebuchadnezzar acknowledges the sovereignty of "the king of heaven," specifically for his ability to humble those walking in pride (v. 34[37]). In these words Newsom finds affirmation that Nebuchadnezzar has indeed been transformed:

43 This is contra Pace, who argues that the truncated version of the king's first-person account makes these "characteristic phrases from the Hebrew Bible...take on new connotations, suggesting that God may act capriciously" (Daniel, 144). 
That Nebuchadnezzar has not yet again misunderstood the purpose of the divine revelation, as he seemed to do in chs. 2 and 3, is confirmed by the concluding verse of the chapter. Not only does Nebuchadnezzar refer to the Most High explicitly as the "King of heaven," a term unique in the Hebrew Bible (cf. 5:23); he also praises God precisely because of God's ability to humble the arrogant. ${ }^{44}$

It seems that Nebuchadnezzar has finally learned that his own great kingship was "utterly derivative, utterly contingent, and totally dependent upon the divine will." 45

\section{THE EFFECT OF THE STRUCTURE}

Daniel 4 recounts events in which the greatest king of the day was judged and humbled by the Most High God, such that he came to acknowledge the superiority of that God and his eternal kingdom. The author uses a first-person narrative structure because, as Newsom notes, it contributes to the fully rounded character of Nebuchadnezzar in the book. As the culmination of the Nebuchadnezzar cycle of stories (Dan 2-4), this final account features him as the primary witness to his transformation. ${ }^{46}$

But to what end? Why is it important that Nebuchadnezzar be a "fully rounded character" and that he should narrate the events behind his recognition of the sovereignty of Daniel's God?

First, it is important because of who Nebuchadnezzar was. In terms of the diaspora audience of the book, Nebuchadnezzar was the most notorious king of Babylon, the city that stood for everything proud, idolatrous, and opposed to God. ${ }^{47} \mathrm{He}$ was the king who had changed life forever for the Jewish people, torching the holy city, destroying the temple of YHWH, and taking his people captive. He was the king who made the God of Israel appear weak and even vanquished (Dan 1:1-2). In humbling this king, the God of Israel demonstrated his sovereignty over all kings and kingdoms. By having this king testify to this truth in his own words, the author makes chapter 4 God's vindication of his name at the universal level: The greatest king of the day tells the whole world that the Most High God - the God/god he thought he had defeated - was sovereign over an eternal kingdom and over Nebuchadnezzar himself.

\footnotetext{
44 Newsom, Daniel, 149.

45 W. Sibley Towner, Daniel, IBC (Atlanta: John Knox, 1984), 59-60.

46 Newsom, Daniel, 133.

47 Babylon's depiction in the Bible begins with the tower of Babel in Gen 11. In the rest of the biblical storyline, the city rises to prominence during the time of the prophets, disappears in the wake of Cyrus, and re-emerges at the end of the New Testament as a code word for "Rome" and then as a symbol for a world in opposition to God and Christ's church (1 Pet 5:13; Rev 14:8; 16:19; 17:5; 18:2, 10, 21).
} 
Second, the first-person narrative in Dan 4 is important because of when these events are purported to have happened. In the context of the book of Daniel, chapter 4 falls at the peak of Nebuchadnezzar's reign; the greatest king of the day was at his best, in terms of power and greatness. In the larger story of Israel, the book of Daniel falls in a time when God's people may well have questioned their status as the people of God and his control of world events. Their God was supposed to be the God of all gods, yet they were in exile, without land, king, or temple. To all appearances, YHWH had abandoned them to live under the rule of an idolatrous gentile king. While the people probably remembered what their sacred texts said - that YHWH ruled the whole earth-it would be hard in a diaspora context to see how those things were true.

What they needed to see was a demonstration of their God's rule and reign in all the earth. They needed to see in living colour that their God was superior to their gentile overlords. This need is addressed by the book of Daniel, and specifically in the cycle of Nebuchadnezzar stories. For three chapters, the biblical narrator recounts the Babylonian king's indirect encounters with the superior God of the exiles. Through these encounters, Nebuchadnezzar had acknowledged the superiority of the Most High with respect to knowledge and power (Dan 2:47; 3:28-29), but his confessions were short lived. The profound significance of Dan 4 is that the king himself tells how he came to understand the supremacy of the Most High God. He himself tells how the Most High God humbled him. He himself proclaims the rule of the Most High God. In the inclusio of doxologies, Nebuchadnezzar himself voices the truths that God's people needed to hear from an outsider with the power that the Babylonian king had. The kingdom of their God was eternal. The kingdom of their God was universal. The kingdom of their God would outlast all human kingdoms - even and perhaps especially Nebuchadnezzar's. The people of God needed to hear the vindication of their God before the whole world from the mouth of the king who had destroyed life as they knew it and who had appeared to defeat their God.

\section{E CONCLUSION}

The book of Daniel showcases the sovereignty of God with respect to human sovereigns, kings who often fail to recognize the derived nature of their power. The only fully-rounded character in three chapters, Nebuchadnezzar is the book's premier example of such a king, and Dan 4 portrays him at his worsttaking credit for his greatness and failing to care for all his subjects. But Dan 4 also portrays him at his best, responding appropriately to God's judgment and acknowledging his place in the hierarchy of kingship. That the book's final word on Nebuchadnezzar is spoken by Nebuchadnezzar is significant for how it accomplishes two things: first, it vindicates the God of Israel before the whole 
world, and second, it transforms the king who embodied opposition to God into the paradigm of what a gentile king ought to be. ${ }^{48}$

\section{BIBLIOGRAPHY}

Bar-Efrat, Shimon. Narrative Art in the Bible. New York: T\&T Clark, 2004.

Bottéro, Jean. Religion in Ancient Mesopotamia. Translated by Teresa Lavender Fagan. Chicago: University of Chicago Press, 2001.

Chatman, Seymour. Story and Discourse: Narrative Structure in Fiction and Film. Ithaca, NY: Cornell University Press, 1978.

Collins, John J. Daniel. Hermeneia: A Critical and Historical Commentary on the Bible. Minneapolis: Augsburg, 1993.

Fewell, Danna Nolan. Circle of Sovereignty: Plotting Politics in the Book of Daniel. Nashville: Abingdon, 1991.

Goldingay, John E. Daniel. WBC 30. Dallas: Word, 1989.

Li, Tarsee. The Verbal System of the Aramaic of Daniel: An Explanation in the Context of Grammaticalization. SAIS 8. Leiden: Brill, 2009. https://doi.org/10.1163/ ej.9789004175143.i-200.

Long, V. Philips. The Art of Biblical History. Grand Rapids: Zondervan, 1994.

Lucas, Ernest C. Daniel. AOTC 20. Downers Grove: InterVarsity Press, 2002.

Montgomery, James A. Montgomery, A Critical and Exegetical Commentary on the Book of Daniel. ICC. New York: Scribner's Sons, 1927.

Newsom, Carol A., with Brennan W. Breed. Daniel: A Commentary. OTL. Louisville: Westminster John Knox, 2014.

Niditch, Susan, and Robert Doran, "The Success Story of the Wise Courtier: A Formal Approach," JBL 96 (1977): 179-93. https://doi.org/10.2307/3265877.

Oppenheimer, A. Leo. "The Interpretation of Dreams in the Ancient Near East." TAPA 46, n.s.; Philadelphia: The American Philosophical Society, 1956. https://doi.org /10.2307/1005761.

Pace, Sharon. Daniel. SHBC 17. Macon: Smyth \& Helwys, 2008.

Runge, Steven E. Discourse Grammar of the Greek New Testament: A Practical Introduction for Teaching and Exegesis. Peabody, MA: Hendrickson, 2010.

Runge, Steven E., and Joshua R. Westbury, eds. Lexham Discourse Hebrew Bible. Bellingham, WA: Lexham, 2012.

Seow, C. L. Daniel. Westminster Bible Companion. Louisville, KY: Westminster John Knox, 2003.

Towner, W. Sibley. Daniel. IBC. Atlanta: John Knox, 1984.

Westbury, Josh. "Quotative Frames and the Power of Redundancy." https://academic.logos.com/quotative-frames-and-the-power-of-redundancy/

Widder, Wendy L. Daniel. SGBC. Grand Rapids: Zondervan, 2016.

Wills, Lawrence M. Wills. The Jew in the Court of a Foreign King: Ancient Jewish Court Legends. HDR 26. Minneapolis: Fortress, 1990.

48 Newsom concludes, "Dan 4 humanizes Nebuchadnezzar and indeed presents him in the positive role of the redeemed sinner, completing the development of his character begun in ch. 1," (Daniel, 149). 
214 Widder, "Letting Nebuchadnezzar Speak,” OTE 32/1 (2019): 197-214

Wendy L Widder, Research Associate in the Department of Hebrew, University of the Free State, Bloemfontein, South Africa. E-mail: wenwidder@ gmail.com; ORCID: https://orcid.org/0000-0002-6921-9882. 